\title{
DETERMINANTS OF FOOD CHOICE IN OBESITY
}

\author{
Nur Aisiyah Widjaja ${ }^{1,2}$, Rendi Aji Prihaningtyas ${ }^{1}$ \\ ${ }^{1}$ Department of Child Health, Faculty of Medicine, Airlangga University, Dr. Soetomo General Hospital, Surabaya, \\ Indonesia \\ ${ }^{2}$ Medical Doctoral Program Student at Faculty of Medicine, Airlangga University, Dr. Soetomo General Hospital, \\ Surabaya, Indonesia \\ Correspondence Address: Nur Aisiyah Widjaja, \\ Email : nuril08@yahoo.com,
}

\begin{abstract}
The prevalence of obesity is increasing at all ages in Indonesia. Obesity does not only cause health complications, such as dyslipidemia, cardiovascular disease, cancer, and osteoarthritis but also has a negative effect on a countr's socioeconomic conditions. Previous studies have explained that food choices affect the incidence of obesity. This literature review aims to explain the factors that influence the food choice related to obesity. Genetic and environmental factors affect the food choice in individuals that can cause obesity. Environmental factors play a major influence on food choice, including peers, family, economic status education environmental conditions, stress, and sedentary behavior. Detection of environmental factors that influence food choice can be one of the strategies to prevent obesity.
\end{abstract}

Key words : Obesity, Diet, Food Preference, Food Choice, Adolescents

\begin{abstract}
ABSTRAK
Prevalensi obesitas pada remaja di Indonesia semakin meningkat. Obesitas tidak hanya berdampak pada masalah kesehatan, seperti disipidemia, hipertensi, strok, penyakit jantung, kanker, dan osteoarthritis melainkan juga memiliki efek negatif pada kondisi sosial ekonomi suatu negara. Pemilihan makanan pada remaja terbentuk akibat pengaruh faktor genetik dan lingkungan. Menjelaskan faktor yang mempengaruhi pemilihan makanan pada remaja yang berhubungan dengan obesitas. Pencarian data dilakukan melalui PubMed, Google, dan Google Scholar yang meneliti faktor yang mempengaruhi pemilihan makanan pada remaja yang berhubungan dengan obesitas. Jenis kelamin, pendidikan, sosial ekonomi, teman sebaya, stress, dan faktor genetik mempengaruhi pemilihan makanan pada remaja yang berhubungan dengan obesitas. Deteksi faktor lingkungan yang mempengaruhi pemilihan makanan pada remaja dapat menjadi salah satu strategi pencegahan obesitas pada remaja di Indonesia.
\end{abstract}

Kata kunci : Obesitas, Diet, Preferensi Makanan, Pemilihan Makanan, Remaja.

\section{INTRODUCTION}

In these two decades, the prevalence rate of obesity is increasing in Indonesia in all age groups, including adolescents (Rachmi, Li, $\&$ Alison Baur, 2017). Excess fat accumulation in the body causes obesity. The body mass Index (BMI) describes a person's nutritional status, such as obesity. The IMT obtained from the calculation of body weight $(\mathrm{kg})$ divided by the height of the squared (meter). The BMI describes the status of adolescent nutrition (Roemling \& Qaim, 2012). Obesity is a global problem that causes health and socialeconomic problems (Koyuncuoğlu Güngör, 2014). Obesity can cause a variety of health complications, such as cardiovascular disease (stroke, myocardial infarction, to heart failure) hyperglycemia, dyslipidemia, insulin resistance, and hypertension. Teenage obesity has a high risk of having childhood obesity in the future (Reinehr, 2018). 
The combination of genetic and environmental factors leads to obesity. Some of the risk factors of obesity in Indonesia include lack of healthy food consumption, sedentary behavior, marriage, and high socioeconomic status (Rachmi et al., 2017).

Urbanization causes dietary changes from traditional farming into a food producing industry, one of which is a high calorie diet (Mistry \& Puthussery, 2015). Obesity occurs in low socio-economic conditions in developed countries and negatively correlated with happiness. There is a positive correlation between obesity and happiness in Indonesia and is demonstrated with high socio-economic status (Sohn, 2017). The lifestyle and behavior of teenagers related to socio-economic status affects the occurrence of obesity. Another study mentioned that there was an increase in the incidence of obesity not only in urban areas, but also in rural areas (Roemling \& Qaim, 2012).

Adolescents are a critical period, it is the transition from childhood to adulthood. A total of 1.2 billion adolescents aged 10-19 years in the world based on WHO. Eating behaviors and potentially experiencing health problems occured in adolescents due to physical, emotional, and social changes. Research on the future body fat predictors has been conducted, such as the age of menarche in women in Indonesia and showed no relationship between the two (Sohn, 2017). However, the prevention of obesity in the developing country is not effective (Sohn, 2017). In Indonesia,obese society is not yet became a health problem so that parents support and motivation for healthy living is still low (Noer, Kustanti, \& Fitriyanti, 2018). Control of food industry is important in preventing adolescents' obesity (Lobstein et al., 2015). The higher exposure of fast food outlets causing the consumption rate to increase and cause increased incidence rate of obesity (Burgoine et al., 2016)). Meanwhile, the success of the treatment of obesity through lifestyle modifications and medicamentose to lower the IMT is still limited (Kelly et al., 2013). Interventions against obesity find obstacles, such as the existence of socioeconomic gaps, so that not all interventions can be applied in developing countries (Chung et al., 2016).

Diet is a health determinant that can be modified. The diversity of diets is dynamic in rural and urban areas (Colozza \& Avendano, 2019). Each country has a different dining environment that can affect food selection (Sproesser et al., 2018). There are genetic and environmental factors that affect the way food selection is potentially causing obesity in adolescents (Campbell, Franks, \& Joseph, 2019). Motivation, food availability, sociocultural conditions, determining the selection of healthy vs unhealthy food (Brug, 2009). Food selection affects the external nutrients (Roemling \& Qaim, 2012). Therefore, the food selection in the end is a behavior that affects a person's health (Friedl et al., 2014).

Prevention of obesity is a more effective strategy than the treatment in developing countries (Ford, Patel, \& Narayan, 2017). Adolescents are the target of obesity prevention program. Teenagers suffering from obesity have a high risk of becoming an adult who also suffers from obesity and causes various health problems (Pandita et al., 2016). Losing weight in adults who suffer from obesity is more difficult. The limitation of losing weight in obesity relates to the high mortality rate. Food selection can be used as one way intervention confronts obesity in teenagers. Detection of factors that influence the way food selection in adolescents gives the opportunity for prevention and intervention of obesity in adolescents. Understanding the factors affecting the selection of healthy or unhealthy foods is necessary to determine health interventions (Verhoeven, Adriaanse, de Vet, Fennis, \& de Ridder, 2015).

The purpose of this research is to explain the factors that affect the selection of 
food related to obesity so that it can be used as a preventive occurrence of obesity or prevention of complications for people with obesity.

Study searches about the factors affecting food selection on obesity are conducted through PubMed, Google Scholar, and Google with the keywords "influence", "food", "selection", "Choice", "Indonesia", "preference", "obesity", "food", "diet". Inclusion criteria include journals in the last 10 years since 2009, using either English or Bahasa Indonesia.

\section{RESULT AND DISCUSSION}

Food selection is a daily activity that becomes a habit. This led to the selection of less conscious food (Jastran, Bisogni, Sobal, Blake, \& Devine, 2009). The more the food selection became habitual then the control of the eating election was increasingly difficult (Hofmann, Friese, \& Roefs, 2009). An understanding of the factors affecting the selection of feeding is necessary as a preventive strategy and intervention of adolescents with obesity. Food selection is influenced by factors, such as gender, weight, socio-economic conditions, culture, lifestyle, and understanding of nutrients (Padulo et al., 2017).

\section{Weight}

Attention to weight affects one's food behaviour and selection (Padulo et al., 2017). The study mentions that subjects who did not pay attention to body weight consumed more chocolate. Meanwhile, subjects who are noticing weight consume less chocolate (Brunner, 2010).

\section{Gender}

In Indonesia, the prevalence of obesity in adolescent male is lower than that of women (Rachmi et al., 2017). Teenage boy tend to choose a healthier diet when compared to teenage girls (Maulida, Nanishi, Green, Shibanuma, \& Jimba, 2016). Gender affects food selection. For example, women prefer food served in smaller portions and attractive appearance than men (Cavazza, Guidetti, \& Butera, 2015).

\section{Family and Peers}

Role models in food selection are found in family and peers. Food availability at home and examples of food selection at home form the eating habits of an individual. For example, if in a family home consuming vegetables and fruits, vegetables and fruits are served daily, and consumed by the family then the selection of food on family members tends to choose vegetables and fruit. The presence of exposure to certain foods affects the selection of foods that make up the eating habits (Houldcroft, Haycraft, \& Farrow, 2014). The selection of food and the practice of childcare in children is a major source of dietary pattern forming in children that can be brought to youth (Larsen et al., 2015). Peers influenced food selection. Teenagers spend most of their time in school with their peers, such as lunchtime and lunch hours. It can affect the selection of unknowingly fed (Houldcroft, Haycraft, \& Farrow, 2014). The impersonation of food selection could occur because the wishes were received in the group (Robinson, Tobias, Shaw, Freeman, \& Higgs, 2011). Young women attending high school and college tend to consume snacks after arriving home, while viewing television, doing assignments, or hanging out with friends (Blum et al., 2019). When gatherings of teenagers tend to have conversations while eating and tend to spend a lot of calories unknowingly. The habit of not breakfast in the family increases the risk of obesity in adolescents (Kurdanti et al., 2015).

Food selection on social groups affects the selection of individual foods in them. The study mentions that the presence of food in 
social groups can change the food selection of a person due to the normal influence of eating on the social group (Nook \& Zaki, 2015). One can eat a lot if he sees others also eat in bulk (Robinson, Sharps, Price, \& Dallas, 2015). Social support, such as advice and information from family and peers affects body image on adolescent obesity, such as support for a healthy life. If there is no social influence or normal being followed, one has a tendency to eat more at his own pace. The positive support will encourage the youth to change the eating behaviors and choices of food done (Maspiyah, Suwandi, \& Efendi, 2015).

\section{Social and culture}

Social and cultural influences the selection of food-related obesity (Hess, Jonnalagadda, \& Slavin, 2016). The suitability and self-monitoring of food is one of the factors that predict the presence of social influences on dietary intake (Spanos, Vartanian, Herman, \& Polivy, 2015). Cultural differences in food selection motivation can change eating behaviors and can differ in each country. For example, in Spain, Ireland, the Netherlands, and Portugal, prices are the most important food selection factor. Meanwhile, the attraction of the food is the most important food selection factor in the UK, Germany, and Norway. In Poland, the natural content of food is the main food selection factor (Markovina et al., 2015). Meanwhile, the social norms of eating in the community also influenced the formation and development of obesity (Higgs \& Thomas, 2016). Westernized lifestyle cause adolescents to choose food outdoors instead of family cuisine and tend to choose high-calorie foods (Janssen, Davies, Richardson, \& Stevenson, 2018).

\section{Economic Status}

Economic Status was also affects the selection of foods related to obesity (Hess, Jonnalagadda, \& Slavin, 2016). FFrom the studies in Surabaya, Bandung, and Yogyakarta showed that the social environment around adolescents also influenced the decision to consume fast food (Sudiyarto, Yuliati, Uhertiana, \& Pratiwi, 2018). However, moving from rural to urban is not necessarily changing one's dietary preference (Colozza \& Avendano, 2019). The availability of fast food around the youth increases the amount of consumption of these foods. Higher socioeconomic status leads to a tendency to consume food outside of the growing number of households in adolescents. Consumption of food outdoors is associated with higher consumption of fat and energy, as well as fewer intake of micronutrients. It increases the risk of obesity in adolescents (Lachat et al., 2012). Food selection in adolescents who are less socially able to economically influenced by comfort and price. In adolescents who are more socially able to be found that it does not always consume healthier foods. The higher the socioeconomic conditions, the greater the tendency to choose unhealthy food (Maulida, Nanishi, Green, Shibanuma, \& Jimba, 2016). The food industry has an influence on child food preferences that can be carried into adulthood (Lobstein et al., 2015).

\section{Enviromental}

The ward has a great influence on eating a person (Higgs \& Thomas, 2016). Obsogenic environments increase the risk of obesity, such as easy access to high calorie foods and technologies, such as gadgets and televisions that cause decreased physical activity as well as the emergence of sleep disorders (Coborn, Houser, Perez-Leighton, \& Teske, 2017). The incidence rate of obesity increases in all countries along with the global food system which causes processed foods to be easily obtained and younger is found in the surrounding environment (Swinburn et al., 2011). Food availability in the environment affects food selection. Obesity is associated 
with the availability of food outlets in the surrounding environment selling unhealthy food (Townshend \& Lake, 2016).

The repeated exposure of certain foods can change food selection (Houldcroft et al., 2014). As for example, exposure to snacks gained at supermarkets increases the risk of unhealthy foods or behaviors that want to overeat the particular type of food (Thornton et al., 2013). The higher the exposure to food outlets, the higher the fast food consumption and the risk of obesity increases (Burgoine et al., 2016). However, the systematic review study mentions that there is no link between the environment with food selection (Caspi, Sorensen, Subramanian, \& Kawachi, 2012). The food shopping pattern also determines the selection of food available. The social dynamics of the existing, safe, financial-appropriate, and affordable environment are the choice of food shopping that affects the selection of available foods (Cannuscio, Hillier, Karpyn, \& Glanz, 2014). Modeling in food selection is required to provide a good environmental influence that can be used as a prevention strategy for obesity (Cruwys, Bevelander, \& Hermans, 2015).

\section{Sedentari behavior}

Lack of physical activity, such as sedentary behaviour by watching longer television causes irregularities in food selection. Consuming food while doing activities, such as watching television lowers the level of satisfaction and makes someone eat more. Consumption of high calorie snacks is usually chosen when doing sedentary activity. it inlead to energy buildup and increased risk of obesity (Hess et al., 2016). Screen time accompanied by food consumption makes one less sensitive to the appetite control thereby increasing energy intake. For example, watching television increases the tendency of consuming high calorie foods unknowingly (Roberts, Yaya, \& Manolis, 2014).

\section{Stress}

Another factor affecting the selection of obesity-related foods is motivation, social support, and bullying (Noer et al., 2018). Excessive eating desires against certain foods that make happy and irregular eating behaviors relate to the incidence of obesity (Potenza \& Grilo, 2014). It is often associated with the opportunity to eat and enjoy certain occasions that make one consume unhealthy food or unhealthy cravings (Verhoeven et al., 2015).

The motivation that affects food selection varies. The motivation for health and weight control makes one choose healthy foods, such as fruits, vegetables, nuts, eggs, grains, and poultry products. However, the motivation for the needs and convenience of making someone consume fast food, meat, and snack (Phan \& Chambers, 2016). Not only motivation, food selection is also influenced by emotions. Studies on adults mention that to address negative emotions and social pressures, a person consumes unhealthy food, especially in healthy women (Verhoeven et al., 2015).

\section{Education}

The understanding of healthy eating behaviors in Indonesia is still limited. The low level of education is associated with higher fast food consumption (Burgoine et al., 2016). Teenage girls tend to consume high-fat snacks, high in sugar and salt several times a day because of its cheap price, good taste, attractive packaging, and yet to understand the negative effects of such habits. Most of the snacks consume more than 2 times a day and this leads to a missed meal time (Blum et al., 2019). The study of adolescent obesity in Malang suggests that the reason for consuming fast food is to have a good taste, fast serving, and be a means of gathering with friends (Sudiyarto et al., 2018). Education and health understanding in 
adolescents is necessary to create a nutritional selection of foods. The decision to buy food is often not as needed, for example buying a Makann on the basis of attractive food appearances, prices, brands, comfort, and taste (Torma, Aschemann-Witzel, \& Thøgersen, 2018). The study mentions that exposure to health information may affect the selection of healthy foods (Stöckli, Stämpfli, Messner, \& Brunner, 2016). The evaluation of healthy food perception in adolescents needs to be done to create a nutritious food selection (Bucher, Collins, Diem, \& Siegrist, 2016). Food selection is a habit that must be created early. One can choose food based on price, comfort, and appearance, but can also choose food based on nutrition, health, and free from substance content such as dyes. The value of oneself affects a person's habit. Health values need to be implanted early to build healthy eating habits (Hauser, Nussbeck, \& Jonas, 2013).

\section{Genetic factors}

There is a link between genetic FTO rs9939609 in adolescent obesity that has allel $\mathrm{A}$, rarely consuming fruit $(\mathrm{P}=0.04)$ and more often consume foods that are fried $(\mathrm{P}=0.01)$ compared to adolescent childhood obesity with genotype TT in Minangkabau. Most adolescent obesity with Allel A does not have food preference to fruits (Susmiati, Lipoeto, Surono, \& Jamsari, 2018).

Another genetic component that affects food selection is flavor. Each individual's perception of taste is influenced by genetic factors, such as sweet and bitter tastes mediated by the G-protein-coupled receptor (GPCR). Genetic factors affect the likes and dislikes of certain foods, such as vegetables, fruits, and snacks in adolescents.

\section{CONCLUSION}

Food selection in adolescents is formed due to the influence of genetic and environmental factors. Detection of environmental factors affecting food selection can be one of the strategies for obesity prevention.

\section{REFERENCE}

Blum, L. S., Mellisa, A., Kurnia Sari, E., Novitasari Yusadiredja, I., Liere, M., Shulman, S., ... Tumilowicz, A. (2019). In-depth Assessment of Snacking Behavior in Unmarried Adolescent Girls Living in Urban Centers of Java, Indonesia. Maternal \& Child Nutrition, e12833.

https://doi.org/10.1111/mcn.12833

Brug, J. (2009). Determinants of healthy eating: Motivation, abilities and environmental opportunities. Family Practice, 25(SUPPL. 1). https://doi.org/10.1093/fampra/cmn063

Brunner, T. A. (2010). How weight-related cues affect food intake in a modeling situation. Appetite, 55(3), 507-511. https://doi.org/10.1016/j.appet.2010.08.0 18

Bucher, T., Collins, C., Diem, S., \& Siegrist, M. (2016). Adolescents' perception of the healthiness of snacks. Food Quality and Preference, 50, 94-101. https://doi.org/10.1016/j.foodqual.2016.0 2.001

Burgoine, T., Forouhi, N. G., Griffin, S. J., Brage, S., Wareham, N. J., \& Monsivais, P. (2016). Does neighborhood fast-food outlet exposure amplify inequalities in diet and obesity? A cross-sectional study. American Journal of Clinical Nutrition, 103(6), 1540-1547. https://doi.org/10.3945/ajcn.115.128132

Campbell, E. T., Franks, A. T., \& Joseph, P. V. (2019). Adolescent obesity in the past decade: A systematic review of genetics and determinants of food choice. Journal of the American Association of Nurse Practitioners, 31(6), 344-351. 
https://doi.org/10.1097/JXX.0000000000 000154

Cannuscio, C. C., Hillier, A., Karpyn, A., \& Glanz, K. (2014). The social dynamics of healthy food shopping and store choice in an urban environment. Social Science and Medicine, 122, 13-20. https://doi.org/10.1016/j.socscimed.2014. 10.005

Caspi, C. E., Sorensen, G., Subramanian, S. V., \& Kawachi, I. (2012). The local food environment and diet: A systematic review. Health and Place, 18(5), 11721187.

https://doi.org/10.1016/j.healthplace.201 2.05.006

Cavazza, N., Guidetti, M., \& Butera, F. (2015). Ingredients of gender-based stereotypes about food. Indirect influence of food type, portion size and presentation on gendered intentions to eat. Appetite, 91, 266-272.

https://doi.org/10.1016/j.appet.2015.04.0 68

Chung, A., Backholer, K., Wong, E., Palermo, C., Keating, C., \& Peeters, A. (2016). Trends in child and adolescent obesity prevalence in economically advanced countries according to socioeconomic position: a systematic review: Child obesity trends and socio-economic position. Obesity Reviews, 17(3), 276295. https://doi.org/10.1111/obr.12360

Coborn, J. E., Houser, M. M., Perez-Leighton, C. E., \& Teske, J. A. (2017). Role of Sex and the Environment in Moderating Weight Gain Due to Inadequate Sleep. Current Obesity Reports, 6(4), 397-404. https://doi.org/10.1007/s13679-0170290-7

Colozza, D., \& Avendano, M. (2019). Urbanisation, dietary change and traditional food practices in Indonesia: A longitudinal analysis. Social Science \& Medicine, 233, 103-112. https://doi.org/10.1016/j.socscimed.2019.
06.007

Cruwys, T., Bevelander, K. E., \& Hermans, R. C. J. (2015). Social modeling of eating: A review of when and why social influence affects food intake and choice. Appetite, 86 , $3-18$. https://doi.org/10.1016/j.appet.2014.08.0 35

Ford, N. D., Patel, S. A., \& Narayan, K. M. V. (2017). Obesity in Low- and MiddleIncome Countries: Burden, Drivers, and Emerging Challenges. Annual Review of Public Health, 38(1), 145-164. https://doi.org/10.1146/annurevpublhealth-031816-044604

Friedl, K. E., Rowe, S., Bellows, L. L., Johnson, S. L., Hetherington, M. M., de Froidmont-Görtz, I., ... Hubbard, V. S. (2014). Report of an EU-US Symposium on Understanding Nutrition-Related Consumer Behavior: Strategies to Promote a Lifetime of Healthy Food Choices. Journal of Nutrition Education and Behavior, 46(5), 445-450. https://doi.org/10.1016/j.jneb.2014.05.00 2

Grimm, E. R., \& Steinle, N. I. (2011). Genetics of eating behavior: Established and emerging concepts. Nutrition Reviews, 69(1), 52-60. https://doi.org/10.1111/j.17534887.2010.00361.x

Hauser, M., Nussbeck, F. W., \& Jonas, K. (2013). The impact of food-related values on food purchase behavior and the mediating role of attitudes: A swiss study. Psychology and Marketing, 30(9), 765778. https://doi.org/10.1002/mar.20644

Hess, J. M., Jonnalagadda, S. S., \& Slavin, J. L. (2016). What Is a Snack, Why Do We Snack, and How Can We Choose Better Snacks? A Review of the Definitions of Snacking, Motivations to Snack, Contributions to Dietary Intake, and Recommendations for Improvement. Advances in Nutrition, 7(3), 466-475. 
https://doi.org/10.3945/an.115.009571

Higgs, S., \& Thomas, J. (2016). Social influences on eating. Current Opinion in Behavioral Sciences, 9, 1-6. https://doi.org/10.1016/j.cobeha.2015.10. 005

Hofmann, W., Friese, M., \& Roefs, A. (2009). Three ways to resist temptation: The independent contributions of executive attention, inhibitory control, and affect regulation to the impulse control of eating behavior. Journal of Experimental Social Psychology, 45(2), 431-435. https://doi.org/10.1016/j.jesp.2008.09.01 3

Houldcroft, L., Haycraft, E., \& Farrow, C. (2014). Peer and friend influences on children's eating. Social Development, 23(1), 19-40. https://doi.org/10.1111/sode. 12036

Janssen, H. G., Davies, I. G., Richardson, L. D., \& Stevenson, L. (2018). Determinants of takeaway and fast food consumption: a narrative review. Nutrition Research Reviews, 31(1), 16-34. https://doi.org/10.1017/S0954422417000 178

Jastran, M. M., Bisogni, C. A., Sobal, J., Blake, C., \& Devine, C. M. (2009). Eating routines. Embedded, value based, modifiable, and reflective. Appetite, 52(1), 127-136. https://doi.org/10.1016/j.appet.2008.09.0 03

Kelly, A. S., Barlow, S. E., Rao, G., Inge, T. H., Hayman, L. L., Steinberger, J., ... Daniels, S. R. (2013). Severe Obesity in Children and Adolescents: Identification, Associated Health Risks, and Treatment Approaches. Circulation, 128(15), 16891712.

https://doi.org/10.1161/cir.0b013e3182a5 cfb3

Koliaki, C., Liatis, S., \& Kokkinos, A. (2019). Obesity and cardiovascular disease: revisiting an old relationship.
Metabolism: Clinical and Experimental, 92, 98-107. https://doi.org/10.1016/j.metabol.2018.1 0.011

Koyuncuoğlu Güngör, N. (2014). Overweight and Obesity in Children and Adolescents. Journal of Clinical Research in Pediatric Endocrinology, 129-143. https://doi.org/10.4274/jcrpe.1471

Kurdanti, W., Suryani, I., Syamsiatun, N. H., Siwi, L. P., Adityanti, M. M., Mustikaningsih, D., \& Sholihah, K. I. (2015). Faktor-faktor yang mempengaruhi kejadian obesitas pada remaja. Jurnal Gizi Klinik Indonesia, 11(4), 179 -. https://doi.org/10.22146/ijcn.22900

Lachat, C., Nago, E., Verstraeten, R., Roberfroid, D., Van Camp, J., \& Kolsteren, P. (2012). Eating out of home and its association with dietary intake: A systematic review of the evidence. Obesity Reviews, 13(4), 329-346. https://doi.org/10.1111/j.1467789X.2011.00953.X

Larsen, J. K., Hermans, R. C. J., Sleddens, E. F. C., Engels, R. C. M. E., Fisher, J. O., \& Kremers, S. S. P. J. (2015). How parental dietary behavior and food parenting practices affect children's dietary behavior. Interacting sources of influence? Appetite, 89, 246-257. https://doi.org/10.1016/j.appet.2015.02.0 12

Lobstein, T., Jackson-Leach, R., Moodie, M. L., Hall, K. D., Gortmaker, S. L., Swinburn, B. A., ... McPherson, K. (2015). Child and adolescent obesity: part of a bigger picture. The Lancet, 385(9986), 2510-2520. https://doi.org/10.1016/S0140-

6736(14)61746-3

Markovina, J., Stewart-Knox, B. J., Rankin, A., Gibney, M., de Almeida, M. D. V., Fischer, A., ... Frewer, L. J. (2015). Food4Me study: Validity and reliability 
of Food Choice Questionnaire in 9 European countries. Food Quality and Preference, 45, 26-32. https://doi.org/10.1016/j.foodqual.2015.0 5.002

Maspiyah, M., Suwandi, T., \& Efendi, F. (2015). Eating behavior control model in obese adolescents based on individual beliefs and ideal body image. International Journal of Medical Science and Public Health, 4(6), 756. https://doi.org/10.5455/ijmsph.2015.0511 2014152

Maulida, R., Nanishi, K., Green, J., Shibanuma, A., \& Jimba, M. (2016). Food-choice motives of adolescents in Jakarta, Indonesia: The roles of gender and family income. Public Health Nutrition, 19(15), 2760-2768. https://doi.org/10.1017/S1368980016000 94X

Mistry, S. K., \& Puthussery, S. (2015). Risk factors of overweight and obesity in childhood and adolescence in South Asian countries: a systematic review of the evidence. Public Health, 129(3), 200209.

https://doi.org/10.1016/j.puhe.2014.12.00 4

Noer, E. R., Kustanti, E. R., \& Fitriyanti, A. R. (2018). Perilaku gizi dan faktor psikososial remaja obes. Jurnal Gizi Indonesia, $\quad 6(2), \quad 109$. https://doi.org/10.14710/jgi.6.2.109-113

Nook, E. C., \& Zaki, J. (2015). Social norms shift behavioral and neural responses to foods. Journal of Cognitive Neuroscience, 27(7), 1412-1426. https://doi.org/10.1162/jocn_a_00795

Padulo, C., Carlucci, L., Manippa, V., Marzoli, D., Saggino, A., Tommasi, L., ... Brancucci, A. (2017). Valence, familiarity and arousal of different foods in relation to age, sex and weight. Food Quality and Preference, 57, 104-113. https://doi.org/10.1016/j.foodqual.2016.1

\subsection{0}

Pandita, A., Sharma, D., Pandita, D., Pawar, S., Tariq, M., \& Kaul, A. (2016). Childhood obesity: Prevention is better than cure. Diabetes, Metabolic Syndrome and Obesity: Targets and Therapy, 9, 83-89. https://doi.org/10.2147/DMSO.S90783

Phan, U. T. X., \& Chambers, E. (2016). Motivations for choosing various food groups based on individual foods. Appetite, 105, 204-211. https://doi.org/10.1016/j.appet.2016.05.0 31

Potenza, M. N., \& Grilo, C. M. (2014). How Relevant is Food Craving to Obesity and Its Treatment? Frontiers in Psychiatry, 5. https://doi.org/10.3389/fpsyt.2014.00164

Rachmi, C. N., Li, M., \& Alison Baur, L. (2017). Overweight and obesity in Indonesia: prevalence and risk factors-a literature review. Public Health, 147, 20 29.

https://doi.org/10.1016/j.puhe.2017.02.00 2

Reinehr, T. (2018). Long-term effects of adolescent obesity: time to act. Nature Reviews Endocrinology, 14(3), 183-188. https://doi.org/10.1038/nrendo.2017.147

Roberts, J., Yaya, L., \& Manolis, C. (2014). The invisible addiction: Cell-phone activities and addiction among male and female college students. Journal of Behavioral Addictions, 3(4), 254-265. https://doi.org/10.1556/jba.3.2014.015

Robinson, E., Sharps, M., Price, N., \& Dallas, R. (2015). Reprint of: Eating like you are overweight: The effect of overweight models on food intake in a remote confederate study. Appetite, 86, 96-100. https://doi.org/10.1016/j.appet.2014.12.2 07

Roemling, C., \& Qaim, M. (2012). Obesity trends and determinants in Indonesia q. Appetite, 58(3), 1005-1013. https://doi.org/10.1016/j.appet.2012.02.0 53 
Smith, A. D., Fildes, A., Cooke, L., Herle, M., Shakeshaft, N., Plomin, R., \& Llewellyn, C. (2016). Genetic and environmental influences on food preferences in adolescence. American Journal of Clinical Nutrition, 104(2), 446-453. https://doi.org/10.3945/ajcn.116.133983

Sohn, K. (2016). Is age at menarche a good predictor of future body fat? The case of a developing country. Health Care for Women International, 37(11), 12391257.

https://doi.org/10.1080/07399332.2015.1 104314

Sohn, K. (2017). The fatter are happier in Indonesia. Quality of Life Research, 26(2), 393-402. https://doi.org/10.1007/s11136-0161403-6

Spanos, S., Vartanian, L. R., Herman, C. P., \& Polivy, J. (2015). Personality, perceived appropriateness, and acknowledgement of social influences on food intake. Personality and Individual Differences, 87 , $110-115$. https://doi.org/10.1016/j.paid.2015.07.03 4

Sproesser, G., Ruby, M. B., Arbit, N., Rozin, P., Schupp, H. T., \& Renner, B. (2018). The Eating Motivation Survey: Results from the USA, India and Germany. Public Health Nutrition, 21(3), 515-525. https://doi.org/10.1017/S1368980017002 798

Stöckli, S., Stämpfli, A. E., Messner, C., \& Brunner, T. A. (2016). An (un)healthy poster: When environmental cues affect consumers' food choices at vending machines. Appetite, 96, 368-374. https://doi.org/10.1016/j.appet.2015.09.0 34

Sudiyarto, S., Yuliati, N., Uhertiana, I., \& Pratiwi, L. F. L. (2018). Exploring youngest consumers perceptions of traditional foods and fast foods product in Java Island. In THE 9TH
INTERNATIONAL CONFERENCE ON GLOBAL RESOURCE CONSERVATION (ICGRC) AND AJI FROM RITSUMEIKAN UNIVERSITY (p. 30006). https://doi.org/10.1063/1.5061859

Susmiati, Lipoeto, N. I., Surono, I. S., \& Jamsari, J. (2018). Association of fat mass and obesity-associated rs9939609 polymorphisms and eating behaviour and food preferences in adolescent minangkabau girls. Pakistan Journal of Nutrition, 17(10), 471-479. https://doi.org/10.3923/pjn.2018.471.479

Swinburn, B. A., Sacks, G., Hall, K. D., McPherson, K., Finegood, D. T., Moodie, M. L., \& Gortmaker, S. L. (2011). The global obesity pandemic: Shaped by global drivers and local environments. The Lancet, 378(9793), 804-814. https://doi.org/10.1016/S01406736(11)60813-1

Thornton, L. E., Cameron, A. J., McNaughton, S. A., Waterlander, W. E., Sodergren, M., Svastisalee, C., ... Crawford, D. A. (2013). Does the availability of snack foods in supermarkets vary internationally? International Journal of Behavioral Nutrition and Physical Activity, 10. https://doi.org/10.1186/1479-5868-10-56

Torma, G., Aschemann-Witzel, J., \& Thøgersen, J. (2018). I nudge myself: Exploring 'self-nudging' strategies to drive sustainable consumption behaviour. International Journal of Consumer Studies, 42(1), 141-154. https://doi.org/10.1111/ijcs.12404

Townshend, T., \& Lake, A. (2016). Obesogenic environments: Current evidence of the built and food environments. Perspectives in Public Health, 137(1), 38-44. https://doi.org/10.1177/17579139166798 60

Verhoeven, A. A. C., Adriaanse, M. A., de Vet, E., Fennis, B. M., \& de Ridder, D. T. D. 
(2015). It's my party and I eat if I want to. Reasons for unhealthy snacking. Appetite, 84 , 20-27. https://doi.org/10.1016/j.appet.2014.09.0 13 